IZA DP No. 6608

Employment Protection and Fertility:

Evidence from the 1990 Italian Reform

Ervin Prifti

Daniela Vuri

May 2012 


\title{
Employment Protection and Fertility: Evidence from the 1990 Italian Reform
}

\author{
Ervin Prifti \\ University of Rome Tor Vergata \\ Daniela Vuri \\ University of Rome Tor Vergata \\ and IZA
}

Discussion Paper No. 6608

May 2012

IZA

P.O. Box 7240
53072 Bonn
Germany

Phone: +49-228-3894-0

Fax: +49-228-3894-180

E-mail: iza@iza.org

\begin{abstract}
Any opinions expressed here are those of the author(s) and not those of IZA. Research published in this series may include views on policy, but the institute itself takes no institutional policy positions.

The Institute for the Study of Labor (IZA) in Bonn is a local and virtual international research center and a place of communication between science, politics and business. IZA is an independent nonprofit organization supported by Deutsche Post Foundation. The center is associated with the University of Bonn and offers a stimulating research environment through its international network, workshops and conferences, data service, project support, research visits and doctoral program. IZA engages in (i) original and internationally competitive research in all fields of labor economics, (ii) development of policy concepts, and (iii) dissemination of research results and concepts to the interested public.
\end{abstract}

IZA Discussion Papers often represent preliminary work and are circulated to encourage discussion. Citation of such a paper should account for its provisional character. A revised version may be available directly from the author. 


\section{ABSTRACT}

\section{Employment Protection and Fertility: Evidence from the 1990 Italian Reform*}

The aim of this paper is to investigate the effect of Employment Protection Legislation (EPL) on fertility decisions of Italian working women using administrative data. We exploit a reform that introduced in 1990 costs for dismissals unmotivated by a 'fair cause' or 'justified motive' in firms below 15 employees and left firing costs unchanged for bigger firms. We use this quasi-experimental setup to study the hypothesis that increased EPL reduces future job insecurity and positively affects a female worker's proneness to take childbearing decisions. We use a difference in difference (OLS-DID) model to control for possible period-invariant sorting bias and an instrumental variable (IV-DID) model to account for time-varying endogeneity of the treatment status. We find that reduced economic insecurity following a strengthening of the EPL regime has a positive and sizable effect on fertility decisions of Italian working women. This result is robust to a number of checks regarding possible interactions with other policy reforms occurring around 1990, changes in the sample of workers and firms, and use of an alternative set of exclusion restrictions.

JEL Classification: J2, J13, J65

Keywords: fertility, employment protection, difference-in-difference, instrumental variables, policy evaluations

Corresponding author:

Daniela Vuri

University of Rome Tor Vergata

Faculty of Economics

Via Columbia 2

00133 Roma

Italy

E-mail: daniela.vuri@uniroma2.it

\footnotetext{
"We would like to thank John Ermisch, Andrea Ichino, Marco Leonardi, Andrea Salvatori, Mark Taylor, and seminar participants at the Brucchi Luchino Workshop 2010 (Padua), the Joint Empirical Social Science (JESS) Seminars 2010 (ISER), the Labour Lunch at the University of Tor Vergata and the CESifo Conference on Employment and Social Protection 2011 (Munich) for useful comments and suggestions. We acknowledge Laboratorio Revelli (Turin) for providing the WHIP dataset. Any error is the authors' sole responsibility.
} 


\section{Introduction}

Low fertility has plagued developed South European nations since the early eighties with significant economic and fiscal implications. Economic insecurity stemming from unstable job prospects is considered one of the causes pushing women to defer childbearing until full integration in the labor market (OECD Employment outlook, 2000). The existing research on the consequences of economic insecurity on childbearing decisions has focused on the effects of an exiguous set of labor market variables such as past unemployment spells, fixed-term contracts and earnings levels. There may be other unexplored channels through which economic uncertainty may influence fertility decisions. In this paper we shed some lights on the effects of Employment Protection Legislation (EPL, henceforth), considered as a major booster of economic security, on the fertility decision of Italian working women. To this purpose, we exploit a quasi-experimental setup created by a law passed in 1990 that for the first time introduced EPL in small firms (less than 15 employees) but left the protection regime for larger firms unchanged. The differential application of the law according to firm size creates variation of EPL through time and across firms and provides a credible basis for inference.

Italy is an interesting case because during the ten years surrounding the time of the EPL reform it experienced the lowest fertility rate in the EU area with 1.25 children on average per women lagging well behind the replacement level of 2.1 (Eurostat, various years). During the same period Italy had in place the fourth strictest EPL regime in the EU but its application was restricted to firms with more than 15 employees (OECD Employment outlook, 2004). This created a sharp contrast with small firm workers who were totally exempted from any kind of protection and could be easily fired with no advance notice or severance payment. Given that almost $95 \%$ of the productive system in Italy is made up of small firms which employ nearly $60 \%$ of the total number of workers, a large share of the working force falls short of any job protection (Italian National Institute of Statistics, various years). The lack of job protection exposes women to a higher risk of losing their jobs and may have several consequences like for example severely restricting access to house mortgages. Given that the reproductive decision is the last of a series of steps aimed at the gradual construction of stability, like completing education, getting a stable job and buying a house, having an insecure job pushes women to avoid childbearing while still facing high economic uncertainty about their future. In relation to this, Kugler and Pica (2008) show that the 1990 EPL reform reduced the risk of losing the job. In particular, separations fall by a significant $15 \%$ because jobs became harder to destroy. We build on this result and look at how reduced economic uncertainty induced by the strengthening of employment protection affected fertility behavior after the 1990 reform. 
Our study contributes to the existing literature on the economic insecurity and fertility decisions in two ways. First, to the best of our knowledge, no study has looked at the effects of EPL on fertility. Second, we study the relationship between this indicator of economic insecurity, as measured by EPL, and fertility decisions in a causal setup with representative individual data. We are able to identify the effects of EPL comparing fertility choices of small versus large firm's workers before and after the law change, thus using a Difference-in-Difference (DID) approach. One natural concern, in our case, is the endogeneity of the treatment status, stemming from deliberate selfselection of workers into one of the EPL regimes created by the reform. In this paper we explicitly address this concern and isolate a causal pathway from employment protection to childbearing decisions. Initially we use a linear specification of the difference in difference estimator which can account for the endogeneity of the treatment status under the assumption of period-invariant sorting bias. Then we use an IV approach to purgue the estimated effects from the selection bias arising from the possible correlation of the treatment status with time varying unobserved heterogeneity by using an instrumental variables approach. We extensively discuss the identifying assumptions of the two estimators and provide suggestive evidence as well as perform formal tests of their validity. Our main conclusion is that strengthening the EPL increased significantly the probability of having a baby and this result is robust across model specifications and estimation procedures.

The rest of the paper is organized as follows. Section 2 presents a summary of previous research on this topic. Section 3 gives a picture of the institutional aspects of the Italian labor market that brought to the 1990 reform. In Section 4 the econometric methods are discussed in depth while in Section 5 we describe the data used in this study. Section 6 presents the results and Section 7 concludes.

\section{Literature review}

In the theoretical strand of the literature on the link between declining fertility and economic uncertainty two studies are particularly interesting. Summer (2010) shows that higher earnings uncertainty related to the risk of loosing the job reduces fertility. This happens because when labor market risk is high households tend to postpone childbearing and prefer to work more and accumulate savings instead. While this could be initially seen as a temporary decision, infertility risks increase with age and delayed fertility may turn into reduced fertility. Ranjan (1999) establishes that increase in uncertainty about future income induces risk adverse agents to postpone childbearing decisions. This result comes from the assumption that a woman plans to have a child in the future only as long as she receives a positive shock yielding her future income to be higher 
than the current period income. Hence, the higher the uncertainty the higher the probability for her to end up with a baby in a state of the world with a negative shock.

In the empirical literature on this topic several studies support the hypothesis of a negative correlation between fertility and economic uncertainty. A first group of papers focuses on objective measures of economic uncertainty. Ahn and Mira (2001) find that males' past unemployment episodes and temporary contracts are important determinants of marriage delay and fertility decline in Spain. De La Rica and Iza (2005) show that Spanish women holding fixed-term contracts and lacking stable employment prospects delay entry into motherhood compared to female workers holding open-ended contracts. Andersson (2000) finds that Swedish women in a stable employment and with reasonable levels of earnings have much higher propensities to become mothers compared to women less attached to the labor market. Similarly, Adsera (2005) exploiting cross country variation in labor market institutions in different OECD nations documents reduced fertility in countries that have experienced acute unemployment. The mechanism at work here is the increase in women's investment in education and skill acquisition in order to minimize the risk of unemployment. Findings include a positive effect of secure public sector jobs based on permanent contracts and of part-time jobs that reduce women's uncertainty about reconciling work and family. She concludes that balancing work and family is possible only in those countries where institutions reduce the uncertainty connected with childbearing. Using Italian data Bratti et al. (2005) find that women who enjoy a greater amount of employment protection have a higher incentive to return to the labor force in the three years following childbirth compared to female workers in less protected jobs. They conclude that women with highly protected and stable jobs find it easier to combine career and family, while those who are less sheltered by the legislation are more likely to withdraw from the labor market.

A second group of papers focus on subjective measures of economic uncertainty on fertility. Kreyenfeld (2005) and Bhaumik and Nugent (2011), using a panel of German women, study the impact on fertility of the perceived economic uncertainty as measured by the feeling that the personal economic situation is insecure. While the former finds no empirical evidence for the economic uncertainty-fertility nexus, the latter confirms a negative correlation.

Finally, Anderson and Pontusson (2007) focus on the relationship between EPL and economic uncertainty. They find that employment protection is a crucial determinant of economic uncertainty as perceived by the worker and its reduction contributes to increase the perceived stability and continuity of one's employment. 


\section{Institutional background}

The Italian labor market has always been one of the strictest in Europe in terms of EPL and reached the peak of its rigidity by the late seventies (Bertola (1990)). At that time, the position of Italy in the continuous rigidity-flexibility spectrum was determined by the relative bargaining power of the two main players when it comes to labor market regulation, namely labor unions and employers' associations. Following widespread social unrest and intense strike activity in the late sixties the workers' unions could rely on strong popular support. In this context, the first EPL reform was introduced in Italy in 1966 with the law 604. ${ }^{1}$ The pro-working class climate culminated in the adoption of the Charter of workers' rights in 1970 that represents the most serious attempt to transversely regulate a large number of aspects ranging from hiring and firing procedures to minimum wages and workplace safety. The Charter establishes a term of notice that firms with more than 15 employees are required to give to the employee, whose length depends on the tenure of the worker. The worker can also require a communication of the detailed reasons for the dismissal. Article 18 of the Charter also establishes the amount of severance payments that firms with more than 15 employees have to face in case a judge finds the dismissal not based on a worker's misconduct ('fair cause') or on technical reasons related to the production process ('justified motive'). In this case it is up to the worker to choose between reinstatement in the old job, plus a severance package equal to foregone earnings between the date of the dismissal and the date of the sentence, or a severance package consisting of 15 months of salary and the foregone earnings. Nonetheless, firms with less then 15 employees were not mentioned by the Charter and were completely exempted from the employment protection regime for the following twenty years.

In May 1990 the law No.108 extended dismissal restrictions to workers holding an open-ended contract and employed in firms with less than 15 employees. This law introduced costs for dismissals unmotivated by a 'fair cause' or a 'justified motive' in firms with less then 15 employees, while firing costs in firms with more then 15 employees remained unchanged. Under the new regime small firms are also required to respect a given period of notice which is established in the national contract for each category of workers. Moreover, if a judge recognizes the episode as 'unfair' dismissal, it is left to the firm the choice of whether to pay the worker a severance package between 2.5 and 6 months of salary or rehire her (instead of reinstating her in the old job). The reform was largely unexpected as the first news appeared in January 1990, just four months before its definitive approval, leaving a very short window for workers and firms to act in anticipation of its expected effects.

In order to avoid capturing false policy effects, we looked at other policy changes occurring in

\footnotetext{
${ }^{1}$ Bertola and Ichino (1995) offer a detailed review of Italian labor market regulations and reforms up to the early $90-$ s.
} 
the years surrounding the 1990 reform that might have had an effect on fertility. We are aware of two of these, namely immigration laws 943/1986 and 39/1990 which formally allowed family reunions and most importantly programed inflows of non-EU citizens to fulfill local labor demand. Although none of these reforms was intended to have differentiated effects on small and large firms, immigrants might show different fertility behavior according to firm size. We explore possible interactions of the immigration laws with the 1990 reforms in Section 6.2.

A final legislative change approved by the Government in 1991 (law 223) is worth mentioning because it occurred close to the 1990 reform. This norm was aimed at loosening the EPL regime and applied to firms with more than 15 employees by allowing collective dismissals of more than 5 workers. In particular, law 223/1991 'explicitly recognized that external flexibility is justifiable on economic grounds, and offered limited opportunities for trade unions to try and avoid employment reductions' (Bertola and Ichino (1995), p.388). While the 1990 reform reduced the gap of EPL provisions by pulling up protection for small firm workers, the 1991 law further narrowed the gap by pushing down protection in large firms. Should the two reforms interfere with each other, we would be capturing the mixed effects of both an incremental change in the protection of small firm workers and a decremental change in the protection of large firm workers. We discuss this issue in detail in Section 6.2.

Finally, it is worth mentioning the interaction between maternity protection legislation and EPL. When the EPL reform took place, maternity leave was regulated by law 1204/1971 that aimed at avoiding firm decisions around childbirth that could damage the psychological and physical health of the pregnant women or compromise the early development of the child. In particular, the pregnant workers were entitled to a payed mandatory maternity leave of five months (usually two before delivery and three after it). All female workers were eligible for maternity leave irrespective of firms size, sector or tenure. The maternity protection legislation prohibits firms from laying off a women in the period of 21 months, ranging from the beginning of the gestation to one year after delivery, unless there is a 'fair cause' of dismissal. The protection offered by maternity leave legislation is limited in time as the firm would still be able to fire a woman shortly after the 21 months guaranteed period if no EPL were in place. Thus we expect women's fertility decisions to be strongly influenced by the presence or lack of EPL that offers a much wider protection by enhancing job and income stability throughout the working life of the woman. 


\section{Identification strategy}

We are interested in estimating the causal effect of an increase in employment protection on the fertility decisions of working women. More specifically we focus on the average effect of the EPL reform for working women who were actually exposed to the increased protection (average treatment on the treated, ATT henceforth). In order to do so we employ a difference in difference (DID) approach exploiting the quasi-experimental framework provided by the 1990 reform. We compare changes in fertility behavior of small firm workers (treated) who benefited from an increase in EPL after 1990 to changes in fertility of large firm workers (controls) whose EPL regime remained unaltered.

If workers were exogenously assigned to the treatment and control groups, the causal effect of EPL on fertility could be identified by least squares estimation of the following DID specification: ${ }^{2}$

$$
Y_{i t}=\alpha_{1} D_{i t}+\alpha_{2} \text { Post }+\alpha_{3} D_{i t} \times \text { Post }+\alpha_{4} \mathbf{x}_{i t}^{\prime}+u_{i t}
$$

where $Y_{i t}$ is a dummy equal to 1 if the worker $i$ experiences a maternity episode at time $t, D_{i t}$ is a dummy that takes the value 1 if the worker is employed in year $t$ in a firm with 15 or fewer employees and 0 if the worker is employed in a firm with more than 15 employees, the variable Post is a dummy that takes the value of 1 starting in 1992 and zero otherwise. ${ }^{3}$ The coefficient $\alpha_{1}$ captures the effect on childbearing decisions of working in a small firm instead of a large firm irrespective of the time period when this takes place, i.e it represents permanent differences between the treated and controls. The coefficient $\alpha_{2}$ captures the effect on $Y$ of the simple passing of time, i.e. general changes in the economic and social context. The interaction coefficient $\alpha_{3}$ is the effect of interest because it captures the differential impact of the increased EPL on small firm workers after the reform compared to large firm workers. We control for observed characteristics by adding the vector $\mathbf{x}_{i t}$, assumed exogenous, that contains workers' and firms' demographics as well as a full set of year, regional and industry dummies. ${ }^{4}$

\footnotetext{
${ }^{2}$ Our dependent variable is a dummy equal to 1 if a maternity episode is registered during the year and 0 otherwise. Nonetheless, we chose a Linear Probability Model instead of a probit as most of our regressors are categorical and the model is almost saturated. A fully saturated LPM does not suffer from out of range predicted probabilities. We also correct standard errors for heteroschedasticity.

${ }^{3}$ Observations that refer to 1991 are excluded from the sample because births registered in that year contain mixed results of childbearing decisions made both before and after the reform. We discuss the sample selection in Section 5.

${ }^{4}$ When the regressor of interest varies at a group level, like in our case, intra-group correlation of the errors can increase standard errors substantially. Hence, the conventional procedures of estimation of the standard errors that do not take this into account are bound to produce downward biased estimates although coefficient estimates remain unbiased. We use the procedure proposed by Bell and McCaffrey (2002), namely Bias Reduced Linearization, which takes into account both the intraclass correlation of errors and the small
} 
The key identifying assumption is that $\alpha_{3}$ would be zero in the absence of the reform, which means that, on average and conditional on $\mathbf{x}_{i t}$, fertility in large and small firms would have followed parallel trends in absence of the reform. In the linear regression framework of equation 1 this is equivalent to say that the unobserved determinants of fertility for the treated and controls would have followed parallel trends had there been no exposure to the treatment. This last formulation of the identifying assumption implies that the linear DID can handle treatment endogeneity as long as the resulting bias has the same magnitude before and after the reform and therefore can be differenced away (Heckman et al. (1998); Heckman and Smith (1999); Heckman et al. (2006)).

\subsection{Worker's sorting}

One possible threat to this identification strategy is the endogenous sorting of workers into the EPL regime. If the resulting endogeneity bias is not constant in the pre- and post-reform period it cannot be differenced away and the ATT will be biased. The idea behind the sorting is that workers might choose their own EPL regime by selecting the firm they work for. This might bias our results if the sorting mechanism depends on worker characteristics the researcher is not able to control for. Selection of workers in one EPL regime might arise because women in childbearing age faced reduced incentives to choose large firms after the 1990 reform narrowed the protection gap between large and small firms. Hence, some women in childbearing age already working in large firms might have poured into small firms after the reform. Also, new entrants might have chosen small firms after the reforms but would not have done so before the reform. These two selection mechanisms would cause the OLS estimate of the ATT to be positively biased.

In order to check if workers self-select into firms above and below the 15 employees threshold, we adopt three strategies. First, we look at workers' flows across firms before and after the reform to test if workers selected into small firms differently over the period. We run a regression of the probability of workers moving to a small firm on a number of determinants that include the Post-reform dummy. The probit regression is as follows:

$$
P\left(M_{i t} \mid \text { Post }, x_{i} t\right)=\Phi\left(\tau_{1} \text { Post }+\tau_{2} \mathbf{x}_{i t}^{\prime}\right)
$$

where $M_{i t}$ is a dummy equal to 1 if a worker $i$ in year $t$ moves towards a small firm and the other variables $x_{i t}$ are defined as in equation (1). Were the Post-reform dummy coefficient in equation (2) not significant, it would suggest that the propensity to select towards small firms did not change after the reform. This, however, does not guarantee that there are no compositional number of groups. The cluster considered in the OLS estimation is at the period*small firm dummy level. 
changes in the treated and control groups in terms of observed or unobserved characteristics. As an imperfect substitute for the test of parallel trends in unobserved characteristics we look at the trends in observed characteristics in the treated and control groups. In other words, we check whether observable characteristics of the workers are balanced in the neighborhood of the 15 employees threshold before and after the reform (see Leonardi and Pica (2010)). All the observed characteristics are regressed on the post-reform dummy, the small-firm dummy, their interaction and a smooth function of firm size:

$$
x_{i t}=\delta_{1} D_{i t}+\delta_{2} \text { Post }+\delta_{3} D_{i t} \times \text { Post }+\sum_{j=1}^{3} a_{j} \text { Firm size } e_{i t}^{j}+v_{i t}
$$

If the coefficient $\delta_{3}$ is never significant we could argue that the average observed characteristics of female workers in large and small firms followed parallel paths in the pre- and post-reform periods and that there were no (observable) compositional changes of the groups over the two periods. These two checks besides offering an intuitive and simple way to look at workers' sorting also provide suggestive evidence on the validity of the DID identifying assumption. If the propensity to move was the same before and after the reform and the groups remained observationally equivalent on average, then the assumption on parallel trends in unobservables is more likely to hold.

A more formal way to account for the possibility of unbalanced observed characteristics between the treated and controls is offered by the semiparametric difference in difference (SDID) estimator proposed by Abadie (2005). He shows that if the pre-treatment observed characteristics that are thought to be associated with the dynamics of the outcome variable are unbalanced between the treated and the controls then the parallel trends assumption might fail. To avoid this, the same distribution of the covariates is imposed. Formally, the SDID estimator of the ATT is:

$$
E\left[\frac{P(D=1 \mid X)}{P(D=1)} \omega Y\right]
$$

where $\omega=\frac{T-\lambda}{\lambda(1-\lambda)} \frac{D-P(D=1 \mid X)}{P(D=1 \mid X) P(D=0 \mid X)}$ is a weighting factor, $\lambda=\frac{n_{1}}{n_{0}+n_{1}} \in(0,1)$ is the proportion of observations that are observed in the post-treatment period and $n_{0}$ and $n_{1}$ are the number of observations that are observed in the pre- and post-treatment period, respectively. The corrective reweighting is carried out by weighting up or down the distribution of $Y$ among the untreated depending on whether covariates are under - or over-represented in that group. While this estimator eliminates one possible cause of non parallel dynamics in average outcomes it still relies on the untestable assumption of parallel trends of average unobservables in absence of the treatment (see Abadie (2005) for the details). 
As a third check for the DID's common trend assumption we perform a classical placebo test. We re-estimate equation (1) in the pre-reform period only and take 1989 as a placebo reform year. This test is expected to produce statistically insignificant estimates of the interaction term between the small-firm dummy and the fake reform year, thus providing some evidence that prior to the reform there were no differences in fertility trends of small vs. large firm workers.

While these checks give some evidence on the validity of the DID identifying assumption, they cannot say anything in case the sorting bias is not constant in the pre- and post-reform period and therefore it cannot be differenced away through the DID. In order to address this issue we estimate equation (1) by instrumental variables. In this approach identification of the ATT, which is assumed to be homogeneous and common to all individuals, is achieved through the use of instruments which exogenously induce variation in firm choice while other observed and unobserved variables are held constant. ${ }^{5}$ We instrument firm choice in a given year with firm choice in the pre-reform years, namely in 1988 and 1989. The pre-reform treatment status is exogenous to the extent that workers did not act in anticipation of the EPL reform by sorting into small firms before the reform was actually passed. Firm size dummies in 1988 and 1989 are determined far enough from the date of the reform and can be seen as exogenous with respect to the reform itself. ${ }^{6}$ The proposed set of exclusion restrictions is thus $\mathbf{Z}=\left\{D_{88}, D_{89}\right\}$. The formal specification is:

$$
\begin{aligned}
Y_{i t} & =\beta_{1} D_{i t}++\beta_{2} \text { Post }+\beta_{3} D_{i t} \times \text { Post }+\beta_{4} \mathbf{x}_{i t}^{\prime}+u_{i t} \\
D_{i t} & =\gamma_{1} Z_{i t}^{\prime}+\gamma_{2} \text { Post }+\gamma_{3} Z_{i t}^{\prime} \times \text { Post }+\gamma_{4} \mathbf{x}_{i t}^{\prime}+\nu_{i t}
\end{aligned}
$$

The first line in (5) is just equation (1), i.e. the structural form. The second line is the first stage and specifies firm choice as a function of all included exogenous variables in (1) and the exclusion restrictions. The term $D_{i t} \times$ Post is also instrumented using as an instrument $Z_{i t}^{\prime} \times$ Post. We check the sensitivity of the results to an alternative set of exclusion restrictions in Section 6.2.

\section{$5 \quad$ Data and descriptive evidence}

We use administrative data from the Italian Social Security Institute (INPS). This dataset is an employer-employee unbalanced panel covering a 1:90 random sample of all employees working in the private sector in Italy. The data include information on individual characteristics such as sex and

\footnotetext{
${ }^{5} \mathrm{We}$ assume there is no sorting on unobserved gains, and responses to treatment are homogeneous conditional on the X. Only sorting on the level stemming from correlation of $D_{i t}$ and $u_{i t}$ that can be solved by IV is allowed. (Heckman et al. (2006)).

${ }^{6}$ The assumption of no anticipative sorting is also made by Leonardi and Pica (2010) with reference to the same reform.
} 
age of the worker, the initial and the final date of each employment spell, the total gross earnings accumulated over the period, the total number of days and weeks worked, an indicator for parttime status, an occupational qualification code, past redundancy payments and most importantly maternity episodes. Our dependent variable is a dummy equal to 1 if a maternity episode was registered during the year. We can also follow the worker when changing job only as long as she continues to work in the private sector. Unfortunately, it is not possible to track individuals who move to public sector, self-employment, agricultural sector, black market jobs, unemployment or retirement. We also have an employer identifier and a set of variables related to the firm such as the industry in which it operates, the geographic location, the average number of employees, and the initial and in some cases also the final year of activity.

Each record in the original dataset corresponds to a single employment spell when this begins and ends within the same calendar year, while spells which span more than one year are divided into different annual records. We re-organize the data into a person-year longitudinal dataset with one record of employment per year. This implies that if there is more than one employment spell during the year, only the longest spell is included in the data.

Because of its administrative nature, the main drawback of the dataset is that there is very little demographic information on individual characteristics; in particular we do not know the level of education, the marital status and spouse's income. While nothing can be done for the last two variables, we can construct a proxy for education based on the individual's age at entry in the dataset, as in Del Bono and Vuri (2011). ${ }^{7}$

We select women aged between 18 and 46 during the ten-year window 1989-1998. The choice of this time window is motivated by the fact that the fertility variable is recorded with underestimation prior to 1989 according to the data provider, while after 1998 many of the firm variables contain a large number of missing values. As to the exact timing of birth, the data set contains information only on the year when the fertility episode takes place. Hence, year 1991 is excluded from the sample as children born in that year are conceived both before and after the reform. As mentioned in Section 3, we assume that workers do not anticipate the reform. Therefore all fertility episodes registered in 1990 can be safely attributed to the pre-treatment period, while observations in 19921998 are attributed to the post-reform period. Since the reform applied only to workers with

\footnotetext{
${ }^{7}$ We define three education dummies. The "No high school" dummy equals 1 if a woman is observed for the first time in our dataset in the age range $[15,18]$ and 0 otherwise. The "High school" dummy equals 1 if a woman is observed for the first time in our dataset in the age range [19,25] and 0 otherwise. The "University degree" dummy equals 1 if a woman is observed for the first time in our dataset after the age of 26 (included). The last dummy will be subject to a greater measurement error since the entry age becomes uninformative with regards to the level of education after a certain age. Estimates of education effects must be interpreted with caution.
} 
open-ended contracts we exclude from our sample workers holding fixed-term contracts whose use had been liberalized by law 56/1987 in an attempt to increase flexibility in the labor market. ${ }^{8}$

As to the selection of firms, we keep in our sample all firms with a yearly average number of employees greater than 5 and less than 50, hence generating an asymmetric window around the threshold value of 15. This enhances the comparability of the treatment and the control groups, as firms near the cut-off value should be similar in their fundamentals. ${ }^{9}$ We define as small those firms that employ an average number of employees between 5 and 15 units.

Figure 1 shows the fertility rate in small and large firms before and after the 1990 reform. We observe that in the pre-reform period fertility in both groups followed almost parallel paths, with fertility in large firms steadily above that in small firms. In the post-reform period we observe non parallel trends and a shrinking of the fertility gap, possibly due to the narrowing of the protection gap between small and large firms. In particular, in the immediate aftermath of the reform in 1992 the narrowing of the fertility gap is mainly driven by a sharp decline of fertility in large firms and a slight increase of fertility in small firms. After 1993 a positive gap in fertility is re-established between large and small firms, which is, however, smaller than the pre-reform gap. Our goal is exactly to explain what happened to fertility after the increase of EPL in small firms.

Table 1 presents raw means of the fertility rate by firm size in the pre- and post-treatment periods. It shows that in the post-reform period fertility in large firms increased on average by 0.1 percentage points relative to the pre-reform period. While fertility in small firms went up by a larger 1 percentage point in the same period. The difference in the differences amounts to a significant 0.9 percentage points increase in the probability of having a child in small firms compared to large firms after the reform. Overall these double differences of raw means suggest that, following the EPL reform, fertility in small firms increased compared to fertility in large firms. However, causal interpretation may be impaired by other confounders (workers' and firms' characteristics) that might potentially influence fertility.

Table 2 presents descriptive statistics on individuals' and firms' characteristics by firms size, before and after the 1990 reform, and their differences. If exposure to treatment was randomized the means of all regressors would be equal in the two groups. However, as can be seen from columns 3 and 6 , more than half of the differences in the characteristics between the treated and

\footnotetext{
${ }^{8}$ On average approximately $13 \%$ of the workers are excluded each year from the sample because they hold a temporary contract. This exclusion does not threaten our identification strategy since there are no significant differences in the use of temporary contracts between small and large firms in the post-reform period relative to the pre-reform period.

${ }^{9}$ Firms with at most 50 employees make up the economically homogeneous group of Small and Medium Enterprises (SME), which motivates our choice of the upper bound of the [5,50] window. Firms with less than 5 employees were excluded because they are usually family run. Following Kuegler and Pica (2008), in Section 6 we perform a robustness check with the $[5,35]$ window.
} 
the controls are statistically significant. Since the workers are different in terms of their observable characteristics and choose which firm to work for, and hence the EPL regime, we need to control for covariates in the regression analysis in order to shed light on the causal relationship between EPL and fertility, as shown in the following section.

\section{Results}

Table 3 reports regression results from the estimation of equation (1) with the gradual inclusion of an expanding set of covariates. All columns include a full set of year dummies to allow for nonlinear time trends. Column (1) displays estimation results for the case with no control for the covariates $x_{i t}$. The regression estimates confirm a positive constant average treatment effect of the reform that amounts to 0.9 percentage points.

The second column presents results for the specification of equation (1) that adds some women's and firms' demographic variables. Net of the influence of all other variables, the effect of the reform remains significant at 1.2 percentage points. The effects of increased employment protection could be possibly conveyed to fertility decisions of working women through the channel of reduced job and income insecurity. As shown in Kuegler and Pica (2008) the EPL reform reduced separations in small firms by a significant $15 \%$ because jobs became harder to destroy. Our result is also in line with other findings of a negative correlation between job insecurity and fertility (Kreyenfeld (2005); Bhaumik and Nugent (2011); Bernardi et al. (2008)).

Looking briefly at the effect of the other covariates, we obtain a significant negative effect of income on fertility. This confirms predictions of traditional models of fertility according to which a higher wage increases the cost of childbearing by increasing the opportunity cost of time dedicated to such activity in terms of foregone wages (Hotz et al. (1997)). We also find that high educated women with a degree exhibit lower probability of being observed in a maternity episode compared to a woman with a high school diploma. The opposite holds true for women with less than a high school diploma. Our data seem to indicate an inverse U-shaped relation between fertility and education of female workers. This is consistent with a human capital interpretation according to which women with a higher endowment of human capital tend to postpone childbearing or eventually have fewer children (Cigno and Ermisch (1988)). The positive coefficient of job-specific tenure shows that women who are higher up in their career ladder have higher chances of taking a childbearing decision compared to otherwise equivalent less senior female colleagues. A one year increase in tenure increases the probability of having a child by a significant 0.5 percentage points approximately. This might be partly related with an age effect and partly with the higher protection recognized 
to higher tenured positions. While theory predicts that having a part-time job helps women to reconcile work and family commitments and lighten the double burden of the mother-worker (Del Boca et al. 2005; Adsera 2005), we unexpectedly find a negative and statistically significant effect of the part-time indicator. A possible explanation for this result is that in our data women in part time jobs are late comers in the labor market since they are older and have lower tenure, therefore they might have already completed the fertility cycle. Finally, being a blue-collar worker reduces the probability of having a child by as much as 1.9 percentage points compared to white collar workers with the same average observed characteristics.

Column 3 has the full set of covariates including also industry and region of work dummies. ${ }^{10}$ The effect of the reform does not change after their inclusion and all coefficient estimates remain equivalent in terms of magnitude and precision to the ones reported in column (2). Nevertheless, it is important to control for worker's region of work to take into account geographical differences in fertility behavior. It turns out that the probability of having a child for female workers employed in Northern (Southern) regions is considerably higher (lower) compared to an observationally equivalent women working in central Italy. This result could be due to an inadequate supply of child care facilities and local labor market characteristics prevalent in the South which makes reconciling work and family life might be comparatively harder in Southern regions (Del Boca et al. (2005)). Indeed, Kertzer et al. (2009) using similar cohorts of individuals find that living in southern Italy and being employed are associated with declined propensity to marry and a longer waiting time to the first child. Both circumstances are known to contribute to a reduction in fertility rates. The industry within which the firm operates also has some predictive power over a worker's decision to have a child. In fact, being employed in such sectors as finance and utilities positively affects fertility decisions in a significant way compared to the condition of being employed in the manufacturing sector (the excluded category). Conversely, working in the rest of the tertiary (health, education, transport, trade) and in the construction sector negatively affects fertility.

\subsection{Sorting issues}

As seen in Section 4.1 the OLS-DID can handle sorting bias as long as it is constant in the preand post-reform period and can be differenced away. However, nonrandom sorting of workers into small and large firms based on time varying unobservables might cause sorting bias to vary. The IV-DID represents an attempt to correct for time varying endogeneity.

\footnotetext{
${ }^{10}$ For parsimony of space we do not report the coefficients on these two additional sets of dummies, but they are available from the authors on request.
} 
We instrument firm choice in a given year with firm choice in pre-reform years, namely in 1988 and 1989. For the IV identification strategy to be valid it is necessary that our instrument is strongly correlated with firm choice at time $t$ but uncorrelated with the shock in equation (1). In Table 4 we present the results for the first stage regressions of the IV estimates to evaluate the weakness of our instruments. The main concerns raised by weak instruments can be summarized in three points. First, if the instrument is only weakly correlated with firm choice even the slightest correlation between the instrument and the residual of equation (1) might induce large inconsistency in the IV estimate possibly exceeding the inconsistency of the corresponding OLS-DID estimate. Second, finite sample bias of the IV estimate might be unduly inflated if the correlation between the instrument and the choice of firm nears zero. Third, weak instruments can generate inflated standard errors in the second stage and consequent loss of significance of the estimates (Wooldridge (2002)).

We instrument both the small-firm dummy and its interaction with the post-reform dummy using four exclusion restrictions namely the two pre-reform firm size dummies and their interactions with the post-reform dummy. Panel A of Table 4 shows the results for firm choice while in panel B we report the results for the interaction of firm choice with the Post dummy. The three columns contain the same specifications reported in Table 3. In both first stage regressions pre-reform firm size dummies are always significant across the three specifications. F-statistics for the test that the coefficients of the exclusion restrictions are jointly zero are way above the critical level of 10 in all specifications (Staiger and Stock (1997)). In the first two rows of panel C we report results of a Chi square test of under-identification, which is a test of the rank condition for IV identification. Results show that we can always reject the null of reduced rank of the coefficients' matrix of excluded instruments in the first stage regression of all endogenous covariates on all instruments (included and excluded) (Wooldridge (2002)). The last two rows in panel C report the HAC version of the Craig-Donald F statistic and the corresponding critical value. The value of the F-statistic is always high enough to reject the null of weak instruments. ${ }^{11}$ Overall, first stage results in this table show that our instruments are strong predictors of firm choice in a given year thus reassuring us on the relevance of the chosen instruments. Consequently, we can be fairly confident that inconsistency and finite sample bias of the IV estimator are not a concern in our case.

Second stage estimates of the IV approach and related test results are presented in Table 5. As mentioned above, consistency of the IV approach hinges crucially on the assumption that pre-reform firm choice is uncorrelated with the unobserved determinants of fertility. We argued in Section 4 that this is a plausible assumption as long as workers refrained from anticipatively acting upon

\footnotetext{
${ }^{11}$ When the Stock-Yogo critical values were not available the Staiger and Stock 'rule of thumb' of the F statistic being at least 10 for the weak identification to be ignored was used.
} 
the expected effects of the reform. The key result is that the IV estimates are uniformly positive and slightly larger than the OLS counterparts. The estimated effect (1.2 percentage points) in the specification with no regressors (column 1) is close to the corresponding OLS result but imprecisely estimated. In the other two specifications that include regressors the effects of the reform become stronger (2.4 and 2.5 percentage points respectively) than the OLS estimates and are always significant. ${ }^{12}$ Having four instruments for two potentially endogenous variables we can run a test of the over-identifying restrictions. The failure to reject the exclusion of the instruments as a group, as shown in the last two rows in Table 5, indicates that the IV estimates of the effect on fertility of an increase in EPL are consistent.

Taken as a whole the results from regressions estimating the effect of an increase in employment protection on fertility are consistent across methods of estimation and specifications of the conditioning set of regressors. Least squares estimates suggest that the reform raised the probability of having a baby of those who benefited from it by a range of 0.9-1.2 percentage points. Using pre-reform firm size dummies as instruments produces similar results as estimated coefficients range between 1.2 and 2.5 percentage points. In order to test if the OLS estimates are statistically different from the IV we perform a Hausman test. The Hausman test results, as reported at the bottom of Table 5, could not reject the null of exogeneity of firm choice, thus confirming consistency of OLS. This suggests that overall the endogeneity bias resulting from workers' sorting into the preferred EPL regime is not an issue in our context.

\subsection{Sensitivity analysis}

This section shows that our estimates of the effects of the reform stand up to a wide range of robustness checks. We initially perform two checks which, besides offering an intuitive and simple way to look at workers' sorting, provide some evidence on the validity of the DID identifying assumption. First we test whether the propensity to move into small firms changed after the reform. Second, we check if treated and controls remained observationally similar on average. If the propensity to move was the same before and after the reform and there were no major compositional changes in terms of average observed characteristics of the groups then the parallel trends assumption of the DID is more likely to hold. For the first test we run a regression of

\footnotetext{
${ }^{12}$ The reason why the sample size is reduced by almost two thirds in Table 5 concerns the way our instruments are defined. Firm size dummies in 1988 and 1989 are defined only as long as the worker is employed in a firm with a number of employees in the [5,15] range (small firms) or in [16,50] (large firms). If the worker is not recorded in the dataset in these years or is employed in a firm with a number of employees outside the range $[5,50]$ then the dummies will be recorded as missing and those observations will be lost in the IV regressions.
} 
the probability of workers moving to a small firm on a number of determinants that include the Post-reform dummy. The coefficient on the Post-reform variable is -0.111 and not significant (s.e. 0.088) suggesting that the propensity to select into small firms did not change after the reform. For the second check we run a balancing test for all observed characteristics based on equation (3) and the results are reported in Table 6 . We find that female workers in small and large firms are statistically equal along most of the observed characteristics (35 out of 50).

We also estimate a semi-parametric version of the DID proposed by Abadie (2005) described in Section 4.1. This estimator while still exploiting the quasi-experimental setup explicitly corrects for unbalanced pre-treatment observed characteristics that might give rise to non parallel dynamics not associated with the reform. The estimated effect obtained with the SDID is significant (s.e. 0.000) and close in magnitude to the OLS-DID results (0.009). This result reassures us on the robustness of the OLS-DID results to the presence of some unbalanced observed characteristics shown in Table 6 .

As a final check for the DID's common trend assumption we perform a placebo test by focusing on the pre-reform period and using 1989 as a fake year of the reform. Results in Table 7 show statistically insignificant estimates of the interaction coefficient suggesting that prior to the reform there is no evidence of differences in fertility trends of small vs. large firm workers. In the light of these results and of the Hausman test that could not reject consistency of the OLS estimates we can be fairly sure that the OLS-DID identifying assumptions are met and that sorting bias is not a concern in our case.

As mentioned in Section 3 one major threat to our identification strategy is the introduction of law 221 in 1991. The 1991 reform allowed firms to collectively dismiss workers on economic grounds but it applied only to large firms. Hence this reduction of protection might have produced the sharp decrease in births in large firm workers shortly after 1991, as shown in Figure 1, which could drive part of the estimated effect. We explore the sensitivity of results to the 1991 reform by using an alternative control group not affected by the 1991 law. In particular we re-estimate equation (1) after restricting the analysis to small firm workers only and using temporary workers as controls. The rationale for this choice is that the 1990 reform extended EPL only to small firm workers with open ended contracts while small firm workers with temporary contracts were excluded. We compare the change in fertility among women with an open ended contract and among those with temporary contracts before and after the 1990 reform. The coefficient of interest is the interaction between the Post-reform dummy with the Open ended contract dummy. Results are shown in Table 8 and estimates are close to the ones obtained in our main analysis when women working in large firms were used as a control group. This finding suggests that the effect we estimate is not confounded by the 1991 reform and therefore our estimates are only capturing the effects of the 
1990 reform. Moreover, the 1991 reform goes in the opposite direction to the one analyzed in the paper, hence a negative impact on fertility could be expected. However, even if we were capturing the effect of the mixed influence of both reforms, our result could be considered a lower bound of the true effect of the 1990 reform since we find it to be positive and significant.

Finally we test the sensitivity of our results to changes in the sample of workers and in the sample of firms. First, we restrict estimation to Italian workers, leaving out of the sample all immigrants, to avoid interference with other reforms as mentioned in Section 3. In fact, immigrants might be a threat to our identification strategy if working immigrants, who are known to strongly contribute to fertility, engage in different fertility behaviors according to firm size. Results are reported in panel A of Table 9. The point estimates of the effects of the reform are similar to those of the baseline analysis for both OLS and IV. Second, we re-estimate our models with a differently sized window around the 15 employee threshold to check the sensitivity of the estimates to the arbitrary choice on the 50 employees threshold. Results are shown in panel B of Table 9. When the window defining the sample of firms is reduced to [5-15:16-35], the magnitude and significance of the coefficients remain virtually the same as those obtained with the [5-15,16-50] window.

The reaction to economic insecurity of individuals can be influenced and mediated by some observed characteristics. For this reason we check whether the reform heterogeneously affected different subgroups of the population sharing certain characteristics. Given that EPL increases with tenure we reestimate equation (1) for a subsample of women with at least 2 years of tenure. Also the effects of the increased EPL might have different impacts according to the age group the woman belongs to. Since younger women might find it easier to react to the new protection regime for biological reasons, we reestimate equation (1) for a subsample of women aged 25 to 35 . Results are reported in panel $\mathrm{C}$ and $\mathrm{D}$ of Table 9 , respectively. In both cases the effects are quantitatively similar to those obtained with the full sample and statistically significant. In the light of these further checks we can conclude that our results are robust to the age and tenure profile of the sampled women.

Finally, we check the sensitivity of the results to an alternative set of exclusion restriction. In particular we use firms size dummies in 1989 and in 1990 as instruments, i.e. $\mathbf{Z}_{1}=\left\{D_{89}, D_{90}\right\}$. As mentioned above, firm choice in 1989 should pose a lesser threat to the exogeneity assumption as it is a decision taken further back in time. However workers in 1990 might have deliberately chosen small firms in anticipation of the forthcoming increased protection. We argued in Section 3 that this does not represent an issue in our context because the first public news about the reform appeared in January 1990 and births taking place in 1990 would have been a response to the reform only if conceived within March. Hence, firm size dummy in 1990 is as good as exogenously assigned as long as workers refrain from acting in anticipation of the reform during the two months window spanning 
from January, when news spread out, to March. This is a reasonable assumption as the reform took four months from the first news to pass in Parliament and the initial uncertainty surrounding its actual content or even its definitive approval must have deterred people from anticipatively acting upon its expected effects. Not surprisingly, results (not shown) remain fundamentally the same as those obtained in the main analysis.

\section{Conclusions}

This paper exploits a natural experiment to estimate the impacts on Italian working women's fertility decisions of an increase in employment protection. Despite intense public debate on both employment protection provisions and worrying low fertility levels in Italy and other South European countries, to date we know little about how the propensity to childbearing of working women is affected by the level of protection of their job positions. To the best of our knowledge this paper is the first to bridge the gap between these two phenomena and to isolate a distinct causal pathway from EPL to fertility decisions.

We use individual level administrative data from the Work Histories Italian Panel (WHIP) covering the ten year window 1989-1998. We exploit a reform occurred in 1990 in Italy which increased job protection for small firm workers while leaving the EPL regime of large firms unaltered, thus creating variation in EPL both across firms and in time. This suggests the adoption of a difference-in-difference identification strategy which allows for endogenous sorting of workers as long as the resulting bias is period-constant and can be differenced away. We apply also an instrumental variables approach that corrects any residual time-varying endogeneity. Both estimators produce similar and sizable effects of the increased EPL on fertility. Results indicate that the reform increased the propensity to have a baby by a significant $0.9-2.5$ percentage points. Given the similar magnitude of the estimated effects we confront results from OLS-DID and the IV approach. A Hausman test shows that OLS estimates are consistent and that endogeneity issues are not a concern in our case. We also perform a series of robustness checks that, considered jointly with the Hausman test results, provide suggestive evidence on the validity of the parallel trends assumption of the OLS-DID.

We hypothesize that channel through which the increased EPL exercises its influence on fertility decisions of working women is by reducing job and income insecurity. However, caution must be taken in the interpretation of the results as only private sector workers are sampled. This implies that we cannot investigate the effect of EPL on the fertility behavior of the entire population, thus limiting the external validity of our analysis. 


\section{References}

[1] Abadie A. (2005) 'Semiparametric Difference-in-Differences Estimators'. Review of Economic Studies, 72(1), 1-19

[2] Andersson A. (2000) 'The impact of labour-force participation on childbearing behavior: Procyclical fertility in Sweden during the 1980s and the 1990s'. European Journal of Population, 16(4), 293-333

[3] Adsera A. (2005) 'Vanishing Children: From High Unemployment to Low Fertility in Developed Countries'. American Economic Review, 95(2), 189-193

[4] Ahn N., Mira P. (2001) 'Job bust, baby bust: evidence from Spain'. Journal of Population Economics, 14(3), 505-521

[5] Andersson C., Pontusson J. (2007) 'Workers, worries and welfare states: Social protection and job insecurity in 15 OECD countries'. European Journal of Political Research, 46, 211-235

[6] Bell R.M., McCaffrey D. F. (2002) 'Bias reduction in standard errors for linear regression for multi-stage samples'. Survey Methodology, 28(2), 169-181

[7] Bernardi L., Klarner A., Van der Lippe K. (2008) 'Job insecurity and the timing of parenthood. A comparison between Eastern and Western Germany'. European Journal of Population, 24(3), 287-313

[8] Bertola G. (1990) 'Job security, employment and wages'. European Economic Review, 34(4), 851-879

[9] Bertola G., Ichino A. (1995) 'Crossing the River: A Comparative Perspective on Italian Employment Dynamics'. Economic Policy, 21, 359-420

[10] Bhaumik S. K., Nugent J. B. (2011) 'Real options and demographic decisions: evidence from East and West Germany'. Applied Economics, 43(21), 2739-2749

[11] Bratti M., Del Bono E., Vuri D. (2005) 'New mothers' labor force participation in Italy: the role of job characteristics'. Labour, 19, 79-121

[12] Cigno A., Ermisch J. (1988) 'A microeconomic analysis of the timing of births'. European Economic Review, 33(4), 737-760

[13] De la Rica S., Iza A. (2005) 'Career planning in Spain: Do fixed-term contracts delay marriage and parenthood?'. Review of Economics of the Household, 3(1), 49-73 
[14] Del Boca D., Pasqua S., Pronzato P. (2005) 'Employment and Fertility Decisions in Italy France and the U.K.'. Labour, CEIS, Fondazione Guacomo Brodolini, 19(s1), 51-77

[15] Del Bono E., Vuri D. (2011) 'Job mobility and the gender wage gap in Italy'. Labour Economics, $18(1), 130-142$

[16] Heckman J., Ichimura H., Smith J., Todd P. (1998) 'Characterizing selection bias using experimental data'. Econometrica, 66(5), 1017-1098

[17] Heckman J., Smith J. (1999) 'The pre program earnings dip and the determination of partecipation in social program: implications for simple program evaluations'. NBER WP

[18] Heckman J., Urzua S. Vytlacil E. (2006) 'Understanding Instrumental Variables in Models with Essential Heterogeneity'. The Review of Economics and Statistics, 88(3), 389-432

[19] Hotz V. J., Klerman J. A., Willis R. J. (1997) 'The economics of fertility in developed countries', in Handbook of Population and Family Economics, 1(1), 275-347

[20] Kertzer D.I., White M.J., Bernardi L., Gabrielli G. (2009) 'Italy's Path to Very Low Fertility: The Adequacy of Economic and Second emographic Transition Theories'. European Journal of Population, 25(1), 89-115

[21] Kreyenfeld M.(2005) 'Economic uncertainty and fertility postponement: Evidence from German panel data'. MPIDR WP 2005-034

[22] Kuegler A., Pica G. (2008) 'Effects of employment protection on worker and job flows: Evidence from the 1990 Italian reform'. Labour Economics, 15, 78-95

[23] Leonardi M., Pica G. (2010) 'Employment Protection Legislation and Wages' IZA Discussion Papers 5335.

[24] OECD (2000) 'Employment Outlook' Paris

[25] OECD (2004) 'Employment Outlook' Paris

[26] Ranjan P. (1999) 'Fertility Behaviour under Income Uncertainty'. European Journal of Population, 15, 25-43

[27] Staiger D., Stock J.H. (1997) 'Instrumental variables regression with weak instruments'. Econometrica, 65(3), 557-586 
[28] Summer K. (2010) 'Fertility Choice in a Life Cycle Model with Idiosyncratic Uninsurable Earnings Risk'. WP Georgetown University

[29] Wooldridge, J. M., (2002) 'Econometric Analysis of Cross Section and Panel Data', MIT Press 
Table 1: Fertility rates by timing of the reform and firm size

\begin{tabular}{lccc}
\hline \hline & Pre-treatment & Post-treatment & Small-Large \\
\hline Small firms & 0.0431 & 0.0532 & $0.0101^{* * *}$ \\
& {$[11,983]$} & {$[43,902]$} & \\
Large firms & 0.0531 & 0.0540 & 0.0009 \\
& {$[9,896]$} & {$[37,166]$} & \\
Post - Pre & $-0.0099^{* * *}$ & -0.0009 & $0.0090^{* *}$ \\
\hline \hline \multicolumn{2}{l}{ NOTES Symbols: $* * *$ * }
\end{tabular}

NOTES Symbols: ${ }^{* * *}$ significant at $1 \% ;{ }^{* *}$ significant at $5 \%,{ }^{*}$ significant at $10 \%$. The pre-treatment period refers to years $1989-$ 90 , and the post-reform period to years 1992-98. The sample contains female workers aged between 18 and 46 working in firms with more than 5 and less than 50 employees. Number of individuals in brackets.

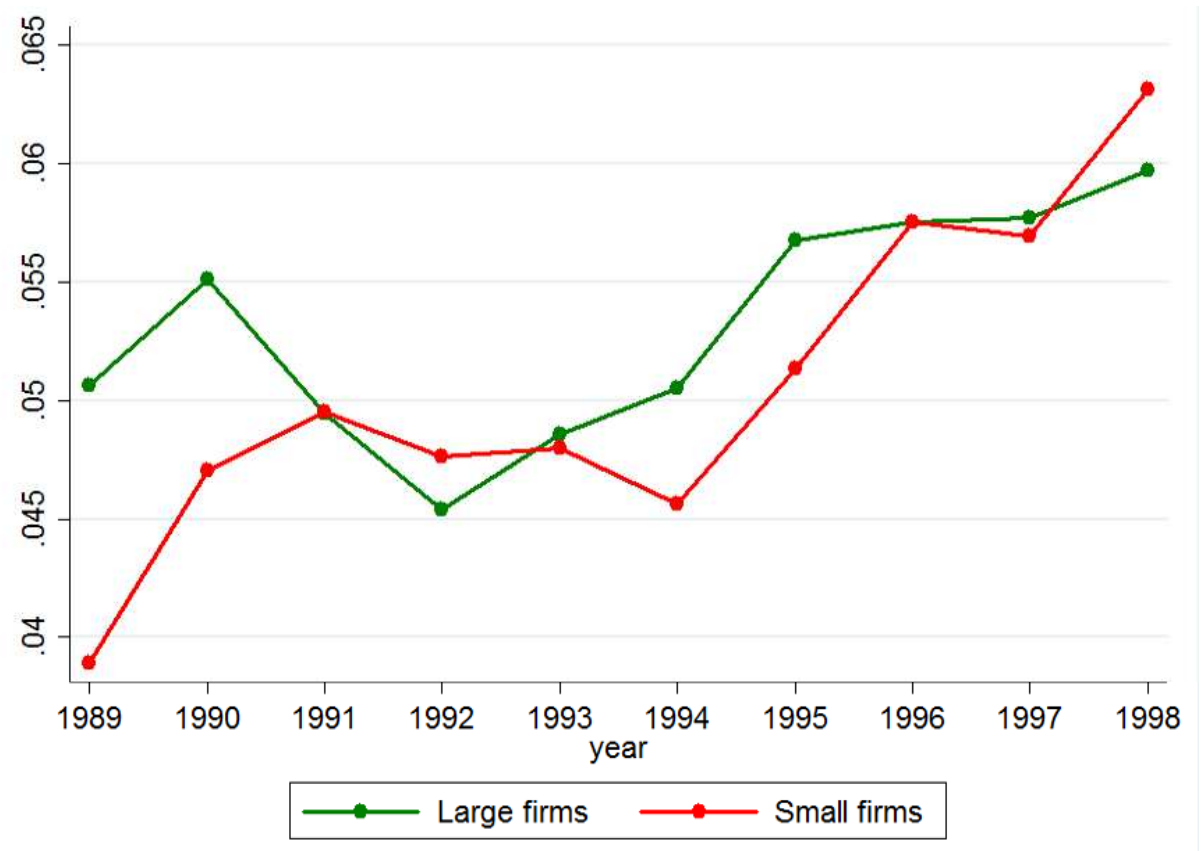

Figure 1: Fertility trends by firm size 
Table 2: Descriptive statistics by firm sizes and timing of the reform

\begin{tabular}{|c|c|c|c|c|c|c|}
\hline \multirow[b]{2}{*}{ Variables } & \multicolumn{2}{|c|}{ Pre-treatment } & \multicolumn{4}{|c|}{ Post-treatment } \\
\hline & Large firms & Small firms & Diff & Large firm & Small firms & Diff \\
\hline Income & 8086.093 & 7278.807 & $807.286 * * *$ & 10605.220 & 9692.976 & $912.240 * * *$ \\
\hline No high school & 0.107 & 0.113 & -0.006 & 0.178 & 0.180 & -0.002 \\
\hline High school diploma & 0.395 & 0.434 & $-0.039 * * *$ & 0.443 & 0.467 & $-0.025 * * *$ \\
\hline University degree & 0.494 & 0.450 & $0.044 * * *$ & 0.368 & 0.344 & $0.0240 * *$ \\
\hline Tenure weeks & 203.533 & 181.623 & $21.910 * * *$ & 279.449 & 260.156 & $19.293 * * *$ \\
\hline Part time & 0.070 & 0.109 & $-0.040 * * *$ & 0.126 & 0.191 & $-0.065 * * *$ \\
\hline Blue collar & 0.639 & 0.571 & $0.069 * * *$ & 0.607 & 0.539 & $0.069 * * *$ \\
\hline Age & 30.330 & 29.543 & $0.787 * * *$ & 31.16 & 30.798 & $0.362 * * *$ \\
\hline Ethnic & 0.037 & 0.035 & 0.002 & 0.052 & 0.047 & $0.005 * * *$ \\
\hline Born north & 0.557 & 0.555 & 0.002 & 0.565 & 0.572 & -0.007 \\
\hline Born center & 0.176 & 0.173 & 0.003 & 0.172 & 0.172 & 0.001 \\
\hline Born south & 0.230 & 0.237 & -0.007 & 0.209 & 0.208 & 0.001 \\
\hline Experience & 274.437 & 253.451 & $20.985 * * *$ & 192.081 & 180.173 & $11.908 * * *$ \\
\hline CIG history & 0.408 & 0.101 & $0.307 * * *$ & 0.327 & 0.108 & $0.219 * * *$ \\
\hline Firm size & 28.061 & 9.288 & $18.773 * * *$ & 28.201 & 9.177 & $19.024 * * *$ \\
\hline Young frim & 0.290 & 0.369 & $-0.079 * * *$ & 0.232 & 0.277 & $-0.045 * * *$ \\
\hline Medium firm & 0.425 & 0.408 & $0.017 * *$ & 0.414 & 0.437 & $-0.023 * * *$ \\
\hline Old firm & 0.285 & 0.223 & $0.062 * * *$ & 0.354 & 0.286 & $0.068 * * *$ \\
\hline Mining & 0.001 & 0.002 & 0.000 & 0.001 & 0.002 & $-0.001 * * *$ \\
\hline Manufactoring & 0.662 & 0.501 & $0.161 * * *$ & 0.597 & 0.466 & $0.131 * * *$ \\
\hline Utilities & 0.002 & 0.001 & $0.001 * *$ & 0.001 & 0.001 & $0.001 * * *$ \\
\hline Construction & 0.020 & 0.027 & $-0.007 * * *$ & 0.022 & 0.029 & $-0.007 * * *$ \\
\hline Trade & 0.140 & 0.221 & $-0.081 * * *$ & 0.152 & 0.217 & $-0.065 * * *$ \\
\hline Hotels and restaurants & 0.044 & 0.08 & $-0.035 * * *$ & 0.053 & 0.092 & $-0.039 * * *$ \\
\hline Transport & 0.012 & 0.010 & 0.002 & 0.017 & 0.012 & $0.005 * * *$ \\
\hline Financial intermediation & 0.009 & 0.012 & $-0.003 * *$ & 0.010 & 0.013 & $-0.003 * * *$ \\
\hline Real estate & 0.086 & 0.114 & $-0.028 * * *$ & 0.117 & 0.137 & $-0.02 * * *$ \\
\hline Public services & 0.024 & 0.033 & $-0.009 * * *$ & 0.029 & 0.031 & -0.002 \\
\hline
\end{tabular}

NOTES Symbols: $* * *$ significant at $1 \% ; * *$ significant at $5 \%,{ }^{*}$ significant at $10 \%$. The pre-treatment period refers to years 1989-90, and the post-reform period to years 1992-98. The sample contains female workers aged between 18 and 46 working in firms with more than 5 and less than 50 employees. Smallfirm identifies a firm with more than 5 and less than 15 (included) employees. Largefirm identifies a firm with more than 15 and less than 50 employees. No high school, High school diploma, and University degree are proxy dummies for education built on the basis of the age the worker is observed for the first time in the dataset (Entry age). Tenure is the number of weeks the worker has been in a specif job. Ethnic is a dummy equal to 1 if the worker is foreign born. Experience is computed as the number of weeks the worker has worked since first observed in the dataset. CIG history is a dummy that equals 1 if the worker has ever received redundancy payments in the past. Firm size is the average number of employees in the firm during a given year. Young firms are those created less than 5 years before 1990. Old firms are those created more than 15 years before 1990. The last 10 rows describe the industry a firm belongs to. 
Table 3: Effects of EPL on fertility: OLS-DID

\begin{tabular}{|c|c|c|c|}
\hline & (1) & $(2)$ & (3) \\
\hline Post & $\begin{array}{l}0.0133^{* * *} \\
(0.0038)\end{array}$ & $\begin{array}{c}-0.0645^{* * *} \\
(0.0041)\end{array}$ & $\begin{array}{c}-0.0620^{* * *} \\
(0.0041)\end{array}$ \\
\hline Small_firm & $\begin{array}{c}-0.0099^{* * *} \\
(0.0033)\end{array}$ & $\begin{array}{c}-0.0100^{* *} \\
(0.0042)\end{array}$ & $\begin{array}{c}-0.0103^{* *} \\
(0.0042)\end{array}$ \\
\hline Postxsmall & $\begin{array}{l}0.0090^{* *} \\
(0.0038)\end{array}$ & $\begin{array}{l}0.0124^{* * *} \\
(0.0036)\end{array}$ & $\begin{array}{l}0.0119^{* * *} \\
(0.0036)\end{array}$ \\
\hline Log_income & & $\begin{array}{c}-0.0280^{* * *} \\
(0.0011)\end{array}$ & $\begin{array}{c}-0.0302^{* * *} \\
(0.0012)\end{array}$ \\
\hline No high school & & $\begin{array}{l}0.0319^{* * *} \\
(0.0029)\end{array}$ & $\begin{array}{l}0.0305^{* * *} \\
(0.0029)\end{array}$ \\
\hline Univ. degree & & $\begin{array}{c}-0.0659^{* * *} \\
(0.0031)\end{array}$ & $\begin{array}{c}-0.0653^{* * *} \\
(0.0031)\end{array}$ \\
\hline Tenure & & $\begin{array}{l}0.0046^{* * *} \\
(0.0000)\end{array}$ & $\begin{array}{l}0.0038^{* * *} \\
(0.0000)\end{array}$ \\
\hline Part_time & & $\begin{array}{c}-0.0301^{* * *} \\
(0.0024)\end{array}$ & $\begin{array}{c}-0.0285^{* * *} \\
(0.0025)\end{array}$ \\
\hline Bluecollar & & $\begin{array}{c}-0.0192^{* * *} \\
(0.0018)\end{array}$ & $\begin{array}{c}-0.0230^{* * *} \\
(0.0020)\end{array}$ \\
\hline Age & & $\begin{array}{l}0.0407^{* * *} \\
(0.0010)\end{array}$ & $\begin{array}{l}0.0407^{* * *} \\
(0.0010)\end{array}$ \\
\hline $\mathrm{Age}^{2}$ & & $\begin{array}{c}-0.0576^{* * *} \\
(0.0014)\end{array}$ & $\begin{array}{c}-0.0575^{* * *} \\
(0.0014)\end{array}$ \\
\hline Ethnic & & $\begin{array}{c}-0.0344^{* * *} \\
(0.0045)\end{array}$ & $\begin{array}{c}-0.0175^{* * *} \\
(0.0047)\end{array}$ \\
\hline Born_south & & $\begin{array}{c}-0.0315^{* * *} \\
(0.0021)\end{array}$ & $\begin{array}{c}-0.0066^{* *} \\
(0.0031)\end{array}$ \\
\hline Born_center & & $\begin{array}{c}-0.0139^{* * *} \\
(0.0022)\end{array}$ & $\begin{array}{c}0.0076^{*} \\
(0.0042)\end{array}$ \\
\hline Experience & & $\begin{array}{c}-0.0003^{* * *} \\
(0.0000)\end{array}$ & $\begin{array}{c}-0.0004^{* * *} \\
(0.0000)\end{array}$ \\
\hline CIG_history & & $\begin{array}{l}0.0026^{* * *} \\
(0.0010)\end{array}$ & $\begin{array}{c}0.0004 \\
(0.0010)\end{array}$ \\
\hline Firm_size & & $\begin{array}{l}0.0024^{* * *} \\
(0.0008)\end{array}$ & $\begin{array}{c}0.0012 \\
(0.0008)\end{array}$ \\
\hline Firm_size $^{2}$ & & $\begin{array}{r}-0.0001^{*} \\
(0.0000)\end{array}$ & $\begin{array}{r}-0.0000 \\
(0.0000)\end{array}$ \\
\hline Firm_size $^{3}$ & & $\begin{array}{c}0.0000 \\
(0.0000)\end{array}$ & $\begin{array}{c}0.0000 \\
(0.0000)\end{array}$ \\
\hline Young_firm & & $\begin{array}{l}0.0101^{* * *} \\
(0.0022)\end{array}$ & $\begin{array}{l}0.0109^{* * *} \\
(0.0022)\end{array}$ \\
\hline Medium_firm & & $\begin{array}{c}0.0019 \\
(0.0020)\end{array}$ & $\begin{array}{c}0.0021 \\
(0.0020)\end{array}$ \\
\hline Year dummies & $Y E S$ & $Y E S$ & $Y E S$ \\
\hline Industry dummies & NO & $N O$ & $Y E S$ \\
\hline Region of work dummies & NO & NO & $Y E S$ \\
\hline $\bar{N}$ & 102947 & 2947 & 2947 \\
\hline $\mathrm{F}$ & 6.7302 & 145.4999 & 73.6071 \\
\hline
\end{tabular}

NOTES Symbols $* p<0.10,{ }^{* *} p<0.05,{ }^{* * *} p<0.01$. Post is a dummy equal to 1 if the worker is observed after the reform. The first column shows OLS estimates of marginal effects of equation (1) when only Post, Small firm and their interaction are included in the RHS. The second column adds all demographic variables except industry and region of work dummies. Column (3) adds the full set of covariates including industry and region of work dummies. 
Table 4: First stage regressions

\begin{tabular}{|c|c|c|c|}
\hline & (1) & (2) & (3) \\
\hline \multicolumn{4}{|l|}{ A. Small } \\
\hline$\overline{D_{88}}$ & $\begin{array}{l}0.0660 * * * \\
(0.0079)\end{array}$ & $\begin{array}{l}-0.1053 * * * \\
(0.0074)\end{array}$ & $\begin{array}{l}-0.1050 * * * \\
(0.0074)\end{array}$ \\
\hline$D_{89}$ & $\begin{array}{l}0.8696 * * * \\
(0.0079)\end{array}$ & $\begin{array}{l}0.3684 * * * \\
(0.0079)\end{array}$ & $\begin{array}{l}0.3675 * * * \\
(0.0079)\end{array}$ \\
\hline$D_{88} \times$ Post & $\begin{array}{l}0.0651 * * * \\
(0.0198)\end{array}$ & $\begin{array}{l}0.1190 * * * \\
(0.0123)\end{array}$ & $\begin{array}{l}0.1184 * * * \\
(0.0122)\end{array}$ \\
\hline$D_{89} \times$ Post & $\begin{array}{c}-0.4438 * * * \\
(0.0198)\end{array}$ & $\begin{array}{l}-0.2621 * * * \\
(0.0121)\end{array}$ & $\begin{array}{l}-0.2617 * * * \\
(0.0120)\end{array}$ \\
\hline $\begin{array}{l}\text { F stat } \\
\text { ( } \mathrm{P} \text { value })\end{array}$ & $\begin{array}{l}24689 \\
\quad(0.0000)\end{array}$ & $\begin{array}{l}838 \\
(0.000)\end{array}$ & $\begin{array}{l}837 \\
\quad(0.0000)\end{array}$ \\
\hline \multicolumn{4}{|l|}{ B. Post $\times$ Small } \\
\hline$\overline{D_{88}}$ & $\begin{array}{c}-0.0000 \\
(0.0000)\end{array}$ & $\begin{array}{l}-0.1567 * * * \\
(0.0067)\end{array}$ & $\begin{array}{l}-0.1562 * * * \\
(0.0067)\end{array}$ \\
\hline$D_{89}$ & $(.) \dagger$ & $\begin{array}{l}-0.4560 * * * \\
(0.0070)\end{array}$ & $\begin{array}{l}-0.4579 * * * \\
(0.0070)\end{array}$ \\
\hline$D_{88} \times$ Post & $\begin{array}{l}0.1311 * * * \\
(0.0202)\end{array}$ & $\begin{array}{l}0.1806 * * * \\
(0.1353)\end{array}$ & $\begin{array}{l}0.1799 * * * \\
(0.0135)\end{array}$ \\
\hline$D_{89} \times$ Post & $\begin{array}{l}0.4258 * * * \\
(0.0201)\end{array}$ & $\begin{array}{l}0.5908 * * * \\
(0.1353)\end{array}$ & $\begin{array}{l}0.5911 * * * \\
(0.0132)\end{array}$ \\
\hline $\begin{array}{l}\mathrm{F} \text { stat } \\
\text { (P value) }\end{array}$ & $\begin{array}{l}661 \\
(0.0000)\end{array}$ & $\begin{array}{l}6209 \\
\quad(0.0000)\end{array}$ & $\begin{array}{l}6172 \\
\quad(0.0000)\end{array}$ \\
\hline \multicolumn{4}{|l|}{ C. Tests } \\
\hline $\begin{array}{l}\text { Under-id }\left(\chi^{2}\right) \\
\text { (P value) }\end{array}$ & $(.) \dagger$ & $\begin{array}{l}623 \\
(0.0000)\end{array}$ & $\begin{array}{l}620 \\
(0.0000)\end{array}$ \\
\hline $\begin{array}{l}\text { Weak-id (F-stat) } \star \\
\text { (Critical value } 5 \%)\end{array}$ & $\begin{array}{l}4000 \\
(11.04)\end{array}$ & $\begin{array}{l}478 \\
(11.04)\end{array}$ & $\begin{array}{l}473 \\
(11.04)\end{array}$ \\
\hline
\end{tabular}

NOTES Symbols $* p<0.10,{ }^{* *} p<0.05,{ }^{* * *} p<0.01$. The specifications in columns 1-3 are the same as those of the corresponding columns in Table 3. Panel A refers to the first endogenous variable and shows coefficients estimates on the four exclusion restrictions and results for an F-statistics that the four coefficients are jointly zero. Panel B repeats results for the other endogenous variable Post $\times$ Small. The first two rows of panel C show results from a Chi square test of under-identification, which is the Kleibergen-Paap test of the rank condition for IV identification. The last two rows report of panel $\mathrm{C}$ show the $\mathrm{F}$ statistic and the corresponding critical values of a test of weak identification, which is the Kleibergen-Paap test that the excluded instruments are correlated with the endogenous regressors, but only weakly. $\star$ Heteroschedasticity-robust version of the test statistic. $†$ The variable $D 89$ is dropped for collinearity reasons. The under-identification test statistic is not computed for this reason. 
Table 5: Effects of EPL on fertility: IV-DID

\begin{tabular}{|c|c|c|c|}
\hline A. SeCOND Stage & (1) & $(2)$ & (3) \\
\hline Post & $\begin{array}{c}-0.0202^{*} \\
(0.0043)\end{array}$ & $\begin{array}{c}-0.0280^{* *} \\
(0.0211)\end{array}$ & $\begin{array}{c}-0.0281^{* *} \\
(0.0211)\end{array}$ \\
\hline Small_firm & $\begin{array}{c}-0.0103^{* *} \\
(0.0048)\end{array}$ & $\begin{array}{c}0.0261 \\
(0.0229)\end{array}$ & $\begin{array}{c}0.0311 \\
(0.0229)\end{array}$ \\
\hline Post $\times$ Small & $\begin{array}{c}0.0121 \\
(0.0090)\end{array}$ & $\begin{array}{l}0.0216^{* *} \\
(0.0094)\end{array}$ & $\begin{array}{l}0.0224^{* *} \\
(0.0094)\end{array}$ \\
\hline Log_income & & $\begin{array}{c}-0.0695^{* * *} \\
(0.0032)\end{array}$ & $\begin{array}{c}-0.0716^{* * *} \\
(0.0033)\end{array}$ \\
\hline No high school & & $\begin{array}{l}0.0205^{* * *} \\
(0.0078)\end{array}$ & $\begin{array}{l}0.0208^{* * *} \\
(0.0078)\end{array}$ \\
\hline Univ. degree & & $\begin{array}{c}-0.0436^{* * *} \\
(0.0055)\end{array}$ & $\begin{array}{c}-0.0428^{* * *} \\
(0.0055)\end{array}$ \\
\hline Tenure & & $\begin{array}{c}0.0008 \\
(0.0005)\end{array}$ & $\begin{array}{c}0.0002 \\
(0.0005)\end{array}$ \\
\hline Part_time & & $\begin{array}{c}-0.0563^{* * *} \\
(0.0049)\end{array}$ & $\begin{array}{c}-0.0562^{* * *} \\
(0.0049)\end{array}$ \\
\hline Bluecollar & & $\begin{array}{c}-0.0382^{* * *} \\
(0.0032)\end{array}$ & $\begin{array}{c}-0.0435^{* * *} \\
(0.0038)\end{array}$ \\
\hline Age & & $\begin{array}{l}0.0330^{* * *} \\
(0.0023)\end{array}$ & $\begin{array}{l}0.0320^{* * *} \\
(0.0023)\end{array}$ \\
\hline $\operatorname{Age}^{2}$ & & $\begin{array}{c}-0.0489^{* * *} \\
(0.0031)\end{array}$ & $\begin{array}{c}-0.0474^{* * *} \\
(0.0031)\end{array}$ \\
\hline Ethnic & & $\begin{array}{c}-0.0295^{* *} \\
(0.0120)\end{array}$ & $\begin{array}{c}-0.0147 \\
(0.0121)\end{array}$ \\
\hline Born_south & & $\begin{array}{c}-0.0405^{* * *} \\
(0.0037)\end{array}$ & $\begin{array}{c}-0.0096^{*} \\
(0.0052)\end{array}$ \\
\hline Born_center & & $\begin{array}{l}-0.0177^{* * *} \\
(0.0037)\end{array}$ & $\begin{array}{c}-0.0001 \\
(0.0081)\end{array}$ \\
\hline Experience & & $\begin{array}{c}-0.0004^{* * *} \\
(0.0000)\end{array}$ & $\begin{array}{l}-0.0004^{* * *} \\
(0.0000)\end{array}$ \\
\hline CIG_history & & $\begin{array}{c}0.0010 \\
(0.0013)\end{array}$ & $\begin{array}{c}-0.0010 \\
(0.0013)\end{array}$ \\
\hline Firm_size & & $\begin{array}{l}0.0060^{* *} \\
(0.0025)\end{array}$ & $\begin{array}{c}0.0056^{* *} \\
(0.0025)\end{array}$ \\
\hline Firm_size $^{2}$ & & $\begin{array}{c}-0.0001 \\
(0.0001)\end{array}$ & $\begin{array}{c}-0.0000 \\
(0.0001)\end{array}$ \\
\hline Firm_size $^{3}$ & & $\begin{array}{c}-0.0000 \\
(0.0000)\end{array}$ & $\begin{array}{c}-0.0000 \\
(0.0000)\end{array}$ \\
\hline Young_firm & & $\begin{array}{l}0.0108^{* *} \\
(0.0043)\end{array}$ & $\begin{array}{l}0.0113^{* * *} \\
(0.0043)\end{array}$ \\
\hline Medium_firm & & $\begin{array}{c}-0.0050 \\
(0.0034)\end{array}$ & $\begin{array}{c}-0.0040 \\
(0.0034)\end{array}$ \\
\hline Year dummies & $Y E S$ & $Y E S$ & $Y E S$ \\
\hline Industry dummies & NO & $N O$ & $Y E S$ \\
\hline Region of work dummies & NO & NO & $Y E S$ \\
\hline \multicolumn{4}{|l|}{ B. Tests } \\
\hline $\begin{array}{l}\text { Hausman test } \\
\text { (P value) } \\
\text { Over-identification } \\
\text { (P value) } \\
N\end{array}$ & $\begin{array}{c}0.9020 \\
(0.6370) \\
1.1970 \\
(0.5497) \\
39127\end{array}$ & $\begin{array}{c}3.9200 \\
(0.1409) \\
1.4540 \\
(0.4834) \\
39127\end{array}$ & $\begin{array}{c}4.6460 \\
(0.0980) \\
1.921 \\
(0.3826) \\
39127\end{array}$ \\
\hline \multicolumn{4}{|c|}{$\begin{array}{l}\text { NOTES Symbols } * p<0.10,{ }^{* *} p<0.05,{ }^{* * *} p<0.01 \text {. The specifi- } \\
\text { cations in columns } 1-3 \text { are the same as those of the corresponding } \\
\text { columns in Table 3. Panel A shows estimation results of the second } \\
\text { stage regression of the IV approach. The first two rows of panel } \\
\text { B show results of a Hasuman test of endogeneity of the treatment } \\
\text { dummy. The last two rows of panel B show results of the test of } \\
\text { over-identifying restrictions. } \\
\qquad 27\end{array}$} \\
\hline
\end{tabular}


Table 6: Balancing tests for observed characteristics

\begin{tabular}{|c|c|c|}
\hline & $(1)$ & $(2)$ \\
\hline Income & -104.9534 & -92.0411 \\
\hline No high school & -0.0044 & -0.0044 \\
\hline High school diploma & -0.0141 & $-0.0146 *$ \\
\hline University degree & $0.0203 * *$ & $0.0207 * *$ \\
\hline Tenure & 0.0545 & 0.0622 \\
\hline Part time & $0.0259 * * *$ & $0.0247 * * *$ \\
\hline Blue collar & 0.0001 & 0.0018 \\
\hline Age & $0.4243 * * *$ & $* \quad 0.4338 * * *$ \\
\hline Ethnic & -0.0027 & -0.0027 \\
\hline Born north & 0.0093 & 0.0097 \\
\hline Born center & 0.0023 & 0.0021 \\
\hline Born south & -0.0083 & -0.0084 \\
\hline Experience & $9.0772 * * *$ & * $\quad 9.2892 * * *$ \\
\hline CIG history & $0.0881 * * *$ & $0.0908 * * *$ \\
\hline Firm size & $-0.2513 *$ & $0.0000 * * *$ \\
\hline Young frim & $-0.0339 * * *$ & $*-0.0346 * * *$ \\
\hline Medium firm & $0.0400 * * *$ & $* \quad 0.0399 * * *$ \\
\hline Old firm & -0.0061 & -0.0053 \\
\hline Mining & 0.0006 & 0.0006 \\
\hline Manufactoring & $0.0300 * * *$ & $0.0331 * * *$ \\
\hline Utilities & 0.0001 & 0.0001 \\
\hline Construction & 0.0000 & -0.0001 \\
\hline Trade & $-0.0164 * *$ & $-0.0180 * * *$ \\
\hline Hotels and restaurants & 0.0036 & 0.0030 \\
\hline Transport & -0.0026 & -0.0026 \\
\hline Financial intermediation & -0.0004 & -0.0005 \\
\hline Real estate & -0.0078 & -0.0085 \\
\hline Public services & $-0.0070 * * *$ & $*-0.0071 * * *$ \\
\hline Region of work 1 & 0.0000 & 0.0000 \\
\hline Region of work 2 & 0.0023 & 0.0024 \\
\hline Region of work 3 & 0.0001 & 0.0000 \\
\hline Region of work 4 & -0.0025 & -0.0026 \\
\hline Region of work 5 & 0.0029 & 0.0036 \\
\hline Region of work 6 & 0.0006 & 0.0004 \\
\hline Region of work 7 & 0.0059 & 0.0063 \\
\hline Region of work 8 & -0.0014 & -0.0016 \\
\hline Region of work 9 & -0.0056 & -0.0059 \\
\hline Region of work 10 & $0.0060 *$ & $0.0061 *$ \\
\hline Region of work 11 & 0.0039 & 0.0038 \\
\hline Region of work 12 & 0.0016 & 0.0016 \\
\hline Region of work 13 & $-0.0086 * *$ & $-0.0088 * *$ \\
\hline Region of work 14 & -0.0044 & -0.0044 \\
\hline Region of work 15 & 0.0021 & 0.0021 \\
\hline Region of work 16 & 0.0010 & 0.0010 \\
\hline Region of work 17 & -0.0027 & -0.0026 \\
\hline Region of work 18 & -0.0003 & -0.0003 \\
\hline Region of work 19 & $0.0028 *$ & $0.0028 *$ \\
\hline Region of work 20 & 0.0003 & 0.0002 \\
\hline
\end{tabular}

NOTES Symbols * $p<0.10,{ }^{* *} p<0.05, * * * p<$ 0.01. Column 1 has results of a balancing test consisting of the raw double differences for each observed characteristics (Post $\times$ Small coefficient in equation (3) without controlling for a smooth function of firm size). Column 2 shows results for the same balancing test while controlling for a smooth function of firm size (the third degree polynomial in firm size in equation (3)). 
Table 7: Falsification test with different year of reform

\begin{tabular}{|c|c|c|c|}
\hline & (1) & $(2)$ & (3) \\
\hline Post $\times$ Small & $\begin{array}{c}0.0038 \\
(0.0050)\end{array}$ & $\begin{array}{c}0.0038 \\
(0.0047)\end{array}$ & $\begin{array}{c}0.0040 \\
(0.0047)\end{array}$ \\
\hline Year dummies & $Y E S$ & $Y E S$ & $Y E S$ \\
\hline Industry dummies & $\mathrm{NO}$ & $\mathrm{NO}$ & $Y E S$ \\
\hline Region of work dummies & $\mathrm{NO}$ & $\mathrm{NO}$ & $Y E S$ \\
\hline$N$ & 21879 & 21879 & 21879 \\
\hline
\end{tabular}

Table 8: DID based on alternative control group

\begin{tabular}{|c|c|c|c|}
\hline & (1) & (2) & $(3)$ \\
\hline Post $\times$ Open & \multicolumn{2}{|c|}{$\begin{array}{l}0.0164^{* * *} \\
(0.0032)\end{array}$} & $\begin{array}{c}* 0.0079^{* *} \\
(0.0033)\end{array}$ \\
\hline Year dummies & $Y E S$ & $Y E S$ & $Y E S$ \\
\hline Industry dummies & NO & $N O$ & $Y E S$ \\
\hline Region of work dummies & NO & NO & $Y E S$ \\
\hline$N$ & 71865 & 71865 & 71865 \\
\hline
\end{tabular}


Table 9: Robustness checks

\begin{tabular}{|c|c|c|}
\hline & OLS-DID & IV-DID \\
\hline \multicolumn{3}{|l|}{ A. NO FOREIGNERS } \\
\hline Post $\times$ Small & $\begin{array}{l}0.0117^{* * *} \\
(0.0037)\end{array}$ & $\begin{array}{l}0.0235^{* *} \\
(0.0094)\end{array}$ \\
\hline $\mathrm{N}$ & 98,160 & 38,078 \\
\hline \multicolumn{3}{|l|}{ B. [5-15:16-35] WINDOW } \\
\hline Post $\times$ Small & $\begin{array}{l}0.0094^{* *} \\
(0.0039)\end{array}$ & $\begin{array}{l}0.0184^{*} \\
(0.0107)\end{array}$ \\
\hline $\mathrm{N}$ & 91,631 & 33,419 \\
\hline \multicolumn{3}{|l|}{ C. Tenure $>2$ years } \\
\hline Post $\times$ Small & $\begin{array}{l}0.0096^{* *} \\
(0.0048)\end{array}$ & $\begin{array}{l}0.0280 \\
(0.0105)\end{array}$ \\
\hline $\mathrm{N}$ & 67,906 & 25,124 \\
\hline \multicolumn{3}{|l|}{ D. AGE [25-35] } \\
\hline Post $\times$ Small & $\begin{array}{l}0.0170^{* * *} \\
(0.0062)\end{array}$ & $\begin{array}{l}0.0265^{*} \\
(0.0149)\end{array}$ \\
\hline $\mathrm{N}$ & 53,145 & 16,108 \\
\hline
\end{tabular}

